\title{
Macroinvertebrate diversity role in water quality assessment of Winongo and Gajah Wong rivers, Yogyakarta, Indonesia
}

\author{
AMELIA NUGRAHANINGRUM", MARTINA FAIKA HARIANJA, HENDRIAWAN NUGROHO, \\ R.C. HIDAYAT SOESILOHADI ${ }^{\text {}}$ \\ Faculty of Biology, Universitas Gajah Mada. Jl. Teknika Selatan, Sekip Utara, Sleman 55281, Yogyakarta, Indonesia. Tel.: +62-274-580839, \\ "email: nugrahaningrum.amelia@gmail.com, " hidsoesi@gmail.com
}

Manuscript received: 21 March 2016. Revision accepted: 28 June 2017.

\begin{abstract}
Nugrahaningrum A, Harianja MF, Nugroho H, Soesilohadi RCH. 2017. Macroinvertebrate diversity role in water quality assessment of Winongo and Gajah Wong rivers, Yogyakarta, Indonesia. Bonorowo Wetlands 7: 31-37. Winongo and Gajah Wong are primary rivers in Yogyakarta Special Region that have important roles for society and surrounding areas; therefore, periodical river monitoring is needed. River monitoring can be conducted by utilizing macroinvertebrate diversity. This research aimed to study macroinvertebrate diversity and analyze both rivers' water quality. Data were collected at the upstream, the middle, and the downstream, $100 \mathrm{~m}$ each, by transect method. The diversity and the abundance of macroinvertebrates were analyzed. The results showed that the number of macroinvertebrate families at Winongo was 24, while at Gajah Wong was 26. Based on Shannon-Wiener and Margalef Indexes, the highest diversity was at Winongo upstream, while the lowest was at Gajah Wong middle zone. Based on Similarity Index, Winongo and Gajah Wong middle zones had the most similar diversity. Based on both Family Biotic Index (FBI) and BIOTILIK Index scores, Winongo upstream had good water quality, while Gajah Wong middle zone was severely polluted.
\end{abstract}

Keywords: Biodiversity, macroinvertebrates, Winongo, Gajah Wong, Yogyakarta

\section{INTRODUCTION}

Water is a vital natural resource required in various daily activities. The input of pollutants can pollute water bodies due to activities that cause degradation of water quality and alteration in the community of aquatic organisms (Dudgeon et al., 2005; Giorgio et al., 2016). The river is a freshwater habitat vulnerable to pollution and environmental conversion (Dewi 2013). The river current flow is unidirectional and influenced by physiology, geology, climate, flora, fauna, land use, and human activities (Anzani 2012).

Gajah Wong and Winongo are rivers that are located in Yogyakarta Special Region. The water basin of these rivers is divided into 3 parts, namely, the upstream at Sleman district, the middle zone at Yogyakarta City, and the downstream at Bantul district (Permana 2013). Both rivers have unique values for the surrounding community, as they are utilized in household utilities, home industries, agriculture, and factories. The state of both rivers is highly alarming because they are polluted by household and industry wastes (either organic or non-organic), which in turn causes the water to become degraded and could not be used by the surrounding community (BLH DIY 2015).

The water quality in water bodies can be determined by dissolved substances, suspended substances, and aquatic organisms. A biological indicator is a group or a community of organisms whose presence is associated with the condition of the surrounding environment. Macroinvertebrates usefully are utilized as biological indicators because they have a settled habitat. The composition and abundance of macroinvertebrates depend on their tolerance or sensitivity toward altering the environment. Alteration of water quality in macroinvertebrate habitats can influence their composition and abundance; therefore, they can give a more precise picture of the state of a particular river compared to environmental parameters (Stein et al., 2008).

Water quality monitoring is a means to systematically evaluate the alteration of water body quality through the response of aquatic organisms. Biomonitoring is divided into four components such as the bioassessment study of the structure and function of life community, the toxicity bioassays, i.e., study of pollutant effect on life forms, the behavioral assays, i.e., analysis of the sublethal impact on the tested organism, and bioaccumulation study of the contaminant dosage absorbed by the organism and its impact in the food chain. Biomonitoring is useful for evaluating the impacts of development on aquatic ecosystems by acquiring information about the alteration of biological structure and diversity of a particular water body. The information can be used as a long-term barometer of the success of aquatic environmental management (Komarawidjaja and Titiresmi 2006).

Concerning the importance of periodical water quality monitoring, this research aimed to acquire information about macroinvertebrate abundance at Gajah Wong and Winongo rivers of Yogyakarta, Indonesia, and determine the water quality of both rivers. 


\section{MATERIALS AND METHODS}

\section{Study area}

The study area of this research are Winongo and Gajah Wong Rivers. Both rivers were located across
Yogyakarta City, Sleman, and Bantul districts in Yogyakarta Special Region, Indonesia. Near each riverside, there were residential areas. Samples were collected at 6 sample points, each of them representing upstream, middle, and downstream zones (Figure 1 and 2, Table 1).

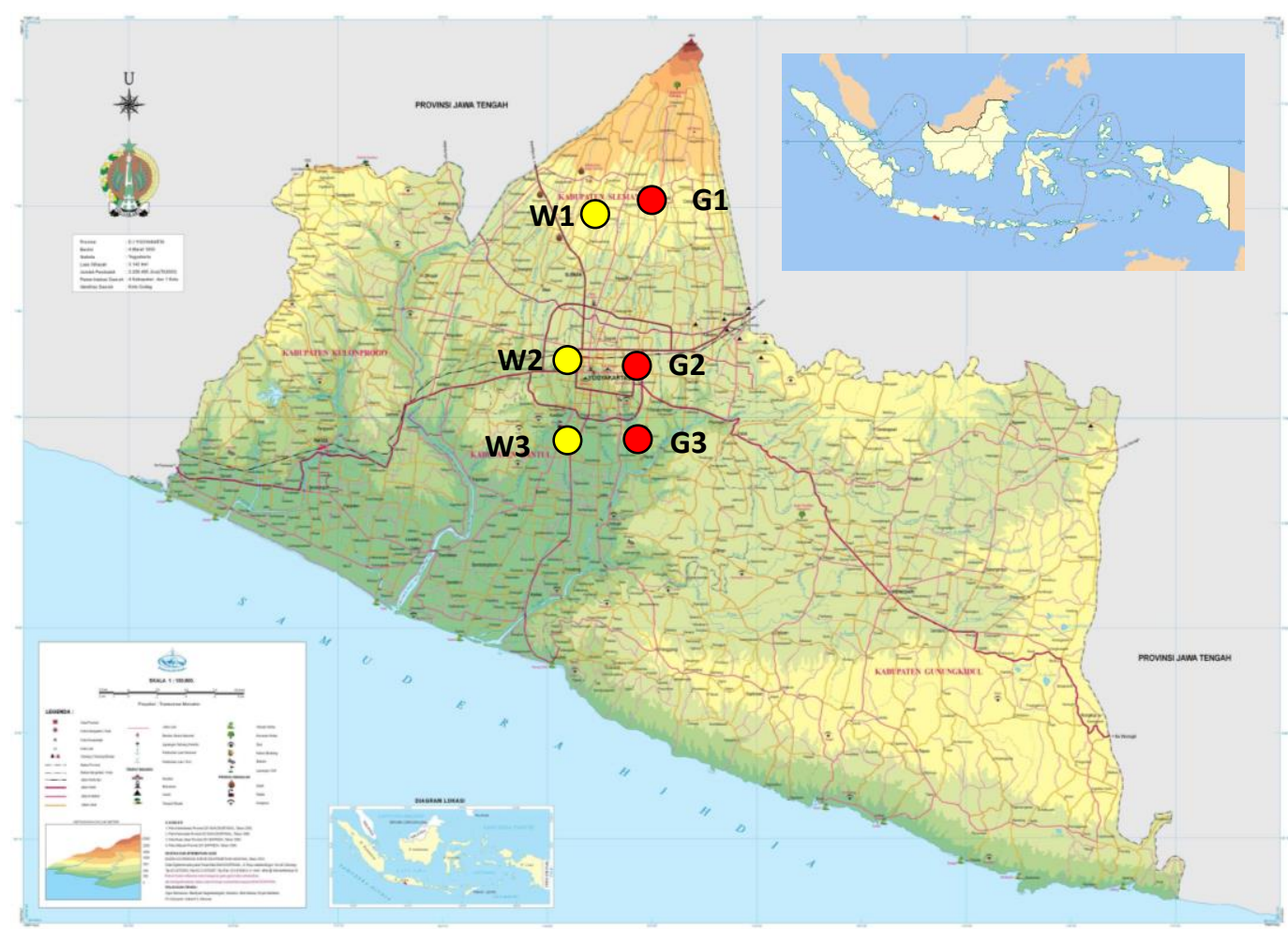

Figure 1.A. Map of Yogyakarta, Indonesia, with six sampling sites. A. W1 (Winongo upstream), B. W2 (Winongo middle), C. W3 (Winongo downstream), D. G1 (Gajah Wong upstream), E. G2 (Gajah Wong middle), F. G3 (Gajah Wong downstream)
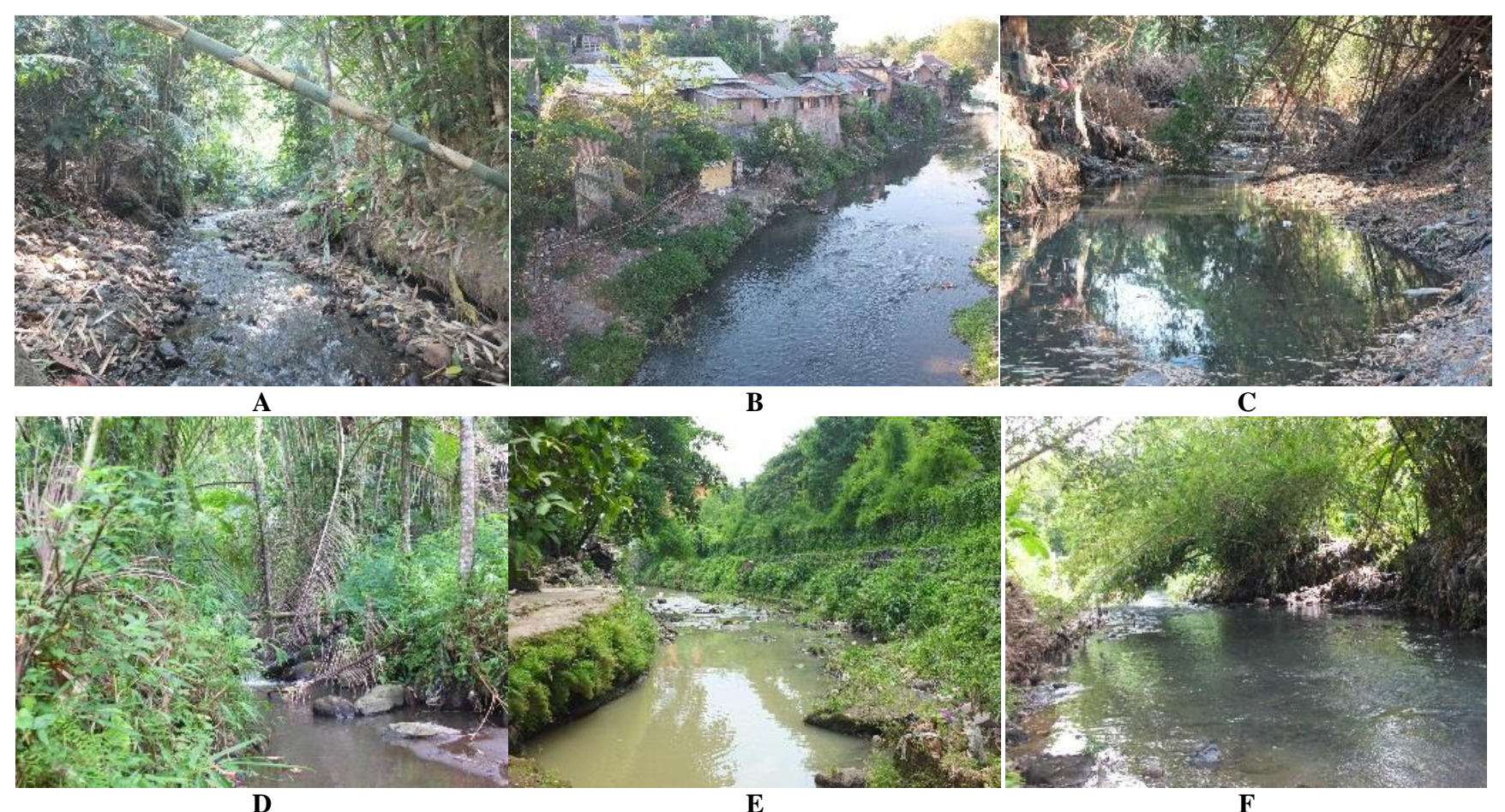

Figure 1.B. Study sites at Winongo and Gajah Wong rivers, Yogyakarta, Indonesia. A. W1 (Winongo upstream), B. W2 (Winongo middle), C. W3 (Winongo downstream), D. G1 (Gajah Wong upstream), E. G2 (Gajah Wong middle), F. G3 (Gajah Wong downstream) 
Table 1. Location of six study sites at Winongo and Gajah Wong rivers, Yogyakarta, Indonesia

\begin{tabular}{lll}
\hline Site & Place & Latitude and Longitude \\
\hline W1 & Winongo upstream & $7^{\circ} 38^{\prime} 03.0^{\prime \prime} \mathrm{S}+110^{\circ} 23^{\prime} 14.9^{\prime \prime} \mathrm{E}$ \\
W2 & Winongo middle & $7^{\circ} 48^{\prime} 04.2^{\prime \prime} \mathrm{S}+110^{\circ} 21^{\prime} 16.8^{\prime \prime} \mathrm{E}$ \\
W3 & Winongo downstream & $7^{\circ} 50^{\prime} 25.6^{\prime \prime} \mathrm{S}+110^{\circ} 20^{\prime} 55.0^{\prime \prime} \mathrm{E}$ \\
G1 & Gajah Wong upstream & $7^{\circ} 38^{\prime} 06.8^{\prime \prime} \mathrm{S}+110^{\circ} 25^{\prime} 15.0^{\prime \prime} \mathrm{E}$ \\
G2 & Gajah Wong middle & $7^{\circ} 47^{\prime} 02.4^{\prime \prime} \mathrm{S}+110^{\circ} 23^{\prime} 46.9^{\prime \prime} \mathrm{E}$ \\
G3 & Gajah Wong downstream & $7^{\circ} 50^{\prime} 28.4^{\prime \prime} \mathrm{S}+110^{\circ} 23^{\prime} 46.4^{\prime \prime} \mathrm{E}$ \\
\hline
\end{tabular}

Table 2. Ecological status categories for Shannon-Wiener Index

\begin{tabular}{ll}
\hline Category & H' \\
\hline High & $>4$ \\
Good & $3.0-4.0$ \\
Moderate & $2.0-3.0$ \\
Poor & $1.0-2.0$ \\
Bad & $0.0-1.0$ \\
\hline
\end{tabular}

Table 3. Degree of pollution based on Family Biotic Index (FBI)

\begin{tabular}{|c|c|c|}
\hline $\begin{array}{l}\text { Family } \\
\text { Biotic Index }\end{array}$ & $\begin{array}{l}\text { Water } \\
\text { Quality }\end{array}$ & Degree of Organic Pollution \\
\hline $0.00-3.75$ & Excellent & Organic pollution unlikely \\
\hline $3.75-4.25$ & Very Good & Possible slight organic pollution \\
\hline $4.26-5.00$ & Good & $\begin{array}{l}\text { Some organic pollution is } \\
\text { probable }\end{array}$ \\
\hline 5.015 .75 & Fair & Fairly substantial pollution likely \\
\hline $5.76-6.50$ & Fairly Poor & Substantial pollution likely \\
\hline $6.51-7.25$ & Poor & Very substantial pollution likely \\
\hline $7.26-10.00$ & Very Poor & Severe organic pollution likely \\
\hline
\end{tabular}

Table 4. River water quality assessment based on BIOTILIK Index

\begin{tabular}{ll}
\hline $\begin{array}{l}\text { Average } \\
\text { Scores }\end{array}$ & Habitat Health Level \\
\hline $2.4-3.0$ & $\begin{array}{l}\text { Healthy, provide diverse and stable habitat } \\
\text { conditions to support biotic life. }\end{array}$ \\
$1.7-2.3$ & $\begin{array}{l}\text { Poorly healthy, provide less variable and less stable } \\
\text { habitat to support biotic life. }\end{array}$ \\
$1.0-1.6$ & $\begin{array}{l}\text { Unhealthy, provide invariable and unstable habitat to } \\
\text { support biotic life. }\end{array}$ \\
\hline
\end{tabular}

\section{Procedures}

Sample collection

This research was conducted in September and October 2015 by the transect method. Macroinvertebrate samples were collected by kick net. The net was put on the river substrate in the opposite direction from the river current. The samples were removed from the net by rubbing off the stones in each plot for 1 minute. The collection was done at 10 plots along 100 meters in each upstream, middle, and downstream zone of the Winongo and Gajah Wong rivers. The current velocity of the rivers was measured at every plot. Samples were placed in flacon bottles and preserved in formaldehyde solution.

\section{Sample analysis}

Samples were documented by camera Pro Summer Fuji Film XS 1 and identified by identification books. Samples were enumerated by eyes.

\section{Data analysis}

The samples were analyzed using the Diversity Index of Shannon-Wiener, Dominance Index, Evenness Index, Similarity Index of Bray-Curtis, Margalef Index, Family Biotic Index, and BIOTILIK Index.

Diversity Index of Shannon-Wiener (Jost 2010)

$\mathrm{H}^{\prime}=-\sum \mathrm{Pi} \ln \mathrm{Pi}, \mathrm{Pi}=\mathrm{ni} / \mathrm{N}$

$H^{\prime}$ : diversity index of Shannon-Wiener, ni: the number of individuals belonging to family $\mathrm{i}, \mathrm{N}$ : the total number of collected individuals

Dominance Index (Simpson Diversity Index) (Firtiana 2005)

$\mathrm{C}=\sum \mathrm{Pi}^{2}, \mathrm{Pi}=\mathrm{ni} / \mathrm{N}$

$\mathrm{C}$ : dominance index, ni: the number of individuals belonging to family $\mathrm{i}, \mathrm{N}$ : the total number of collected individuals

Evenness Index (Heip 1974; Heip et al. 1998)

$\mathrm{e}=\mathrm{H}^{\prime} / \mathrm{H} \max , \mathrm{H} \max =\ln \mathrm{S}$

e: evenness index, H': Shannon-Wiener index, S: the total number of identified families

Similarity Index of Bray-Curtis (Wolda 1981)

$\mathrm{S}_{\mathrm{BC}}=\sum 2 * \min \left(\mathrm{n}_{1 \mathrm{i}}, \mathrm{n}_{2 \mathrm{i}}\right) / \sum \mathrm{n}_{1 \mathrm{i}}+\sum \mathrm{n}_{2 \mathrm{i}}$

$\mathrm{S}_{\mathrm{BC}}$ : similarity index of Bray-Curtis

n1i: the number of individuals of the ith family in sample 1

n2i: the number of individuals of the ith family in sample 2

min: refers to the lower abundance value for the family of the two samples being compared

Margalef Index (Gamito 2009)

$\mathrm{D}_{\mathrm{Mg}}=(\mathrm{S}-1) / \ln \mathrm{N}$

$D_{\text {Mg: }}$ Margalef Index, S: the total number of identified families, N: the total number of collected individuals

Family Biotic Index (Rahayu et al. 2009)

$\mathrm{FBI}=\sum \mathrm{x}_{\mathrm{i}} * \mathrm{t}_{\mathrm{i}} / \mathrm{n}$

FBI $=$ Family Biotic Index

$\mathrm{x}_{\mathrm{i}}=$ the number of individuals belonging to family $\mathrm{i}$

$t_{i}=$ score of tolerance of family $i$

$\mathrm{n}=$ the total number of collected individuals

BIOTILIK Index (Ecoton 2013)

$\mathrm{BI}=\mathrm{X} / \mathrm{N}, \mathrm{X}=\mathrm{xi} * \mathrm{ti}$

BI: BIOTILIK Index

$\mathrm{X}_{\mathrm{i}}=$ the number of individuals belonging to family $\mathrm{i}$

$\mathrm{t}_{\mathrm{i}}=$ score of tolerance of family $\mathrm{i}$

$\mathrm{N}=$ the total number of collected individuals

\section{RESULTS AND DISCUSSION}

\section{Macroinvertebrate diversity}

The highest score of the Shannon-Wiener Diversity Index of macroinvertebrates was 2.412 the upstream of Winongo. The lowest score was 1.205 in the middle of 
Gajah Wong. Based on Puente and Diaz (2008), the upstreams of both locations had moderate ecological conditions. Then, the other locations were included in poor environmental conditions because the range of their scores was 1-2.

Based on Margalef Diversity Index, the upstream of Winongo had the highest score, 3.539. Then, the upstream of Gajah Wong had a score of 2.811. The lowest score was in the middle of Gajah Wong, 1.361. The higher the Margalef score, the higher the macroinvertebrate diversity.

The evenness index of Winongo and Gajah Wong's upstreams was high, i.e., around 0.8. It showed that the macroinvertebrate individuals at the upstream were distributed evenly. The lowest scores of evenness index were at the middle and the downstream of Gajah Wong.

Based on figure 3., the highest score of the Simpson index was 0.432 in the middle of Gajah Wong. The second highest score was 0.390 in the middle of Winongo. It showed that there were dominating families in both zones.
The similarity index of the middle of Winongo and the middle of Gajah Wong was valued the highest, with more than 50\%. It showed that they had similar macroinvertebrate diversity. The other location did not have similar macroinvertebrate diversity.

The correlation value of macroinvertebrate diversity and current velocity was low. The change of current velocity did not directly influence the macroinvertebrate diversity at Winongo and Gajah Wong rivers. Many factors besides current velocity influenced macroinvertebrate diversity.

Based on Family Biotic Index, Winongo upstream had a good status, some organic pollution is probable. The status of Gajah Wong upstream and downstream was fair. Then, the other locations had very poor water quality. Based on the BIOTILIK index, upstreams of Winongo and Gajah Wong were included in slightly polluted water. The middle of Winongo and the downstream of Gajah Wong had fairly polluted water. Then, the middle of Gajah Wong and the downstream of Winongo had heavily polluted water.

Table 1. Macroinvertebrate family at Winongo and Gajah Wong rivers, Yogyakarta, Indonesia

\begin{tabular}{|c|c|c|c|c|c|c|c|}
\hline \multirow{2}{*}{ Group } & \multirow{2}{*}{ Taxa } & \multicolumn{6}{|c|}{ Number of individuals } \\
\hline & & W1 & W2 & & G & $\mathbf{G}$ & G3 \\
\hline \multirow[t]{5}{*}{ Ephemeroptera } & Baetidae & 2 & 0 & 0 & 6 & 0 & 0 \\
\hline & Caenidae & 0 & 0 & 0 & 11 & 0 & 0 \\
\hline & Heptageniidae & 12 & 0 & 0 & 0 & 0 & 0 \\
\hline & Leptophlebiidae & 11 & 0 & 0 & 0 & 0 & 0 \\
\hline & Polymitarcyidae & 0 & 0 & 0 & 22 & 0 & 0 \\
\hline \multirow[t]{2}{*}{ Plecoptera } & Chloroperlidae & 3 & 0 & 0 & 0 & 0 & 0 \\
\hline & Perlidae & 4 & 0 & 0 & 0 & 0 & 0 \\
\hline \multirow[t]{6}{*}{ Trichoptera } & Brachycentridae & 1 & 0 & 0 & 0 & 0 & 0 \\
\hline & Goeridae & 0 & 0 & 0 & 2 & 0 & 0 \\
\hline & Hydropsychidae & 1 & 4 & 1 & 0 & 2 & 58 \\
\hline & Leptoceridae & 1 & 0 & 0 & 0 & 0 & 0 \\
\hline & Philopotamidae & 3 & 0 & 0 & 0 & 0 & 0 \\
\hline & Polycentropodidae & 0 & 0 & 0 & 1 & 0 & 0 \\
\hline Cerithioidea & Pleuroceridae & 27 & 4 & 25 & 10 & 0 & 2 \\
\hline \multirow[t]{3}{*}{ Diptera } & Chironomidae & 1 & 64 & 38 & 18 & 107 & 2 \\
\hline & Simuliidae & 1 & 0 & 0 & 0 & 0 & 0 \\
\hline & Tipulidae & 0 & 0 & 0 & 1 & 0 & 0 \\
\hline \multirow[t]{3}{*}{ Decapoda } & Atyidae & 0 & 0 & 4 & 0 & 0 & 0 \\
\hline & Palaemonidae & 15 & 0 & 0 & 21 & 0 & 0 \\
\hline & Parathelphusidae & 2 & 1 & 0 & 3 & 0 & 2 \\
\hline \multirow[t]{4}{*}{ Hemiptera } & Corixidae & 5 & 0 & 26 & 0 & 1 & 1 \\
\hline & Mesoveliidae & 0 & 0 & 0 & 1 & 0 & 0 \\
\hline & Veliidae & 14 & 0 & 0 & 4 & 0 & 0 \\
\hline & Nepidae & 0 & 0 & 0 & 1 & 0 & 0 \\
\hline Hirudinea & & 0 & 29 & 2 & 0 & 0 & 1 \\
\hline Megaloptera & Sialidae & 0 & 1 & 0 & 0 & 0 & 0 \\
\hline \multirow[t]{4}{*}{ Odonata } & Coenagrionidae & 0 & 0 & 0 & 0 & 0 & 1 \\
\hline & Euphaeidae & 4 & 0 & 0 & 0 & 0 & 0 \\
\hline & Gomphidae & 0 & 0 & 0 & 1 & 0 & 0 \\
\hline & Libellulidae & 0 & 0 & 0 & 0 & 7 & 0 \\
\hline Pulmonata & Lymnaeidae & 0 & 0 & 0 & 0 & 6 & 0 \\
\hline Pulmonata & Physidae & 0 & 3 & 1 & 0 & 0 & 0 \\
\hline Rhynchobdellida & Glossiphoniidae & 0 & 10 & 5 & 0 & 8 & 0 \\
\hline Sorbeoconcha & Thiaridae & 15 & 0 & 0 & 0 & 6 & 43 \\
\hline Tubificina & Tubificidae & 0 & 0 & 4 & 0 & 9 & 0 \\
\hline Veneroida & Corbiculidae & 0 & 0 & 0 & 0 & 0 & 3 \\
\hline Viviparoidea & Viviparidae & 0 & 0 & 0 & 0 & 0 & 2 \\
\hline
\end{tabular}



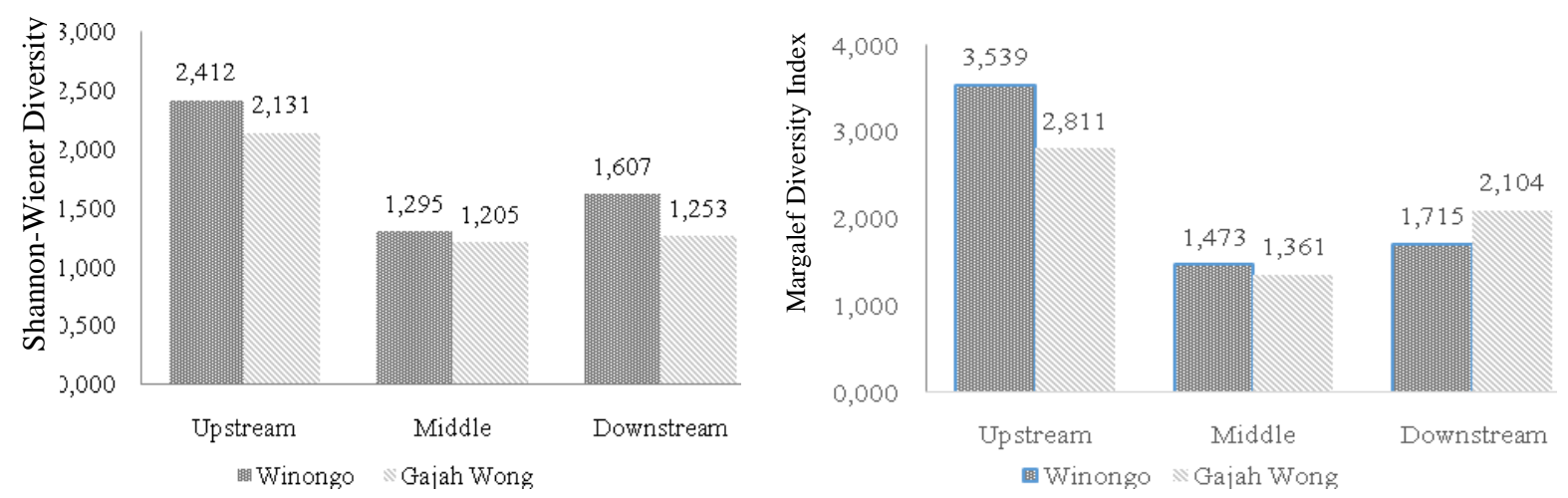

Figure 1. Macroinvertebrate diversity at Winongo and Gajah Wong rivers, Yogyakarta, Indonesia

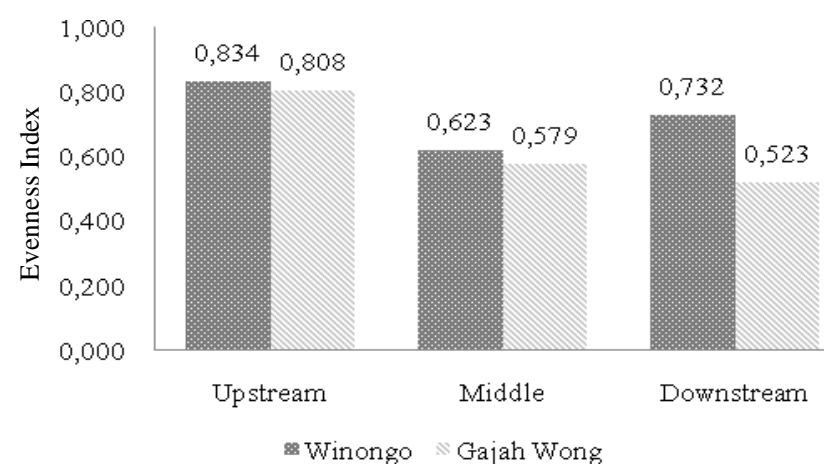

Figure 2. Evenness of macroinvertebrate at Winongo and Gajah Wong rivers, Yogyakarta, Indonesia

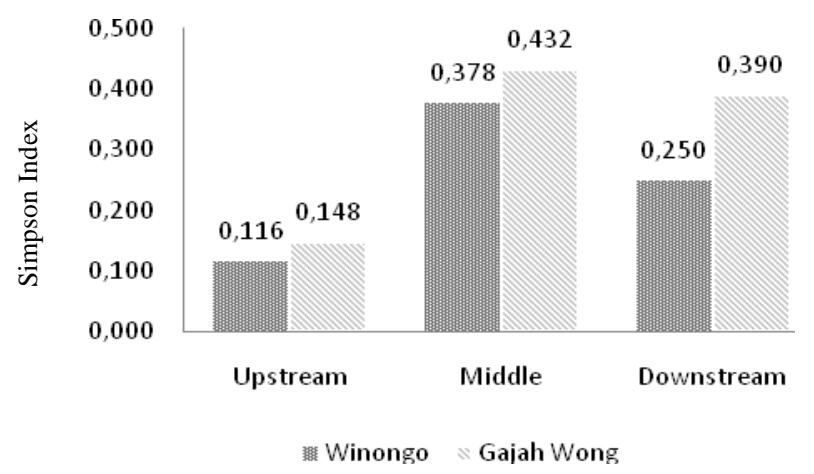

Figure 3. Dominance of macroinvertebrate at Winongo and Gajah Wong rivers, Yogyakarta, Indonesia

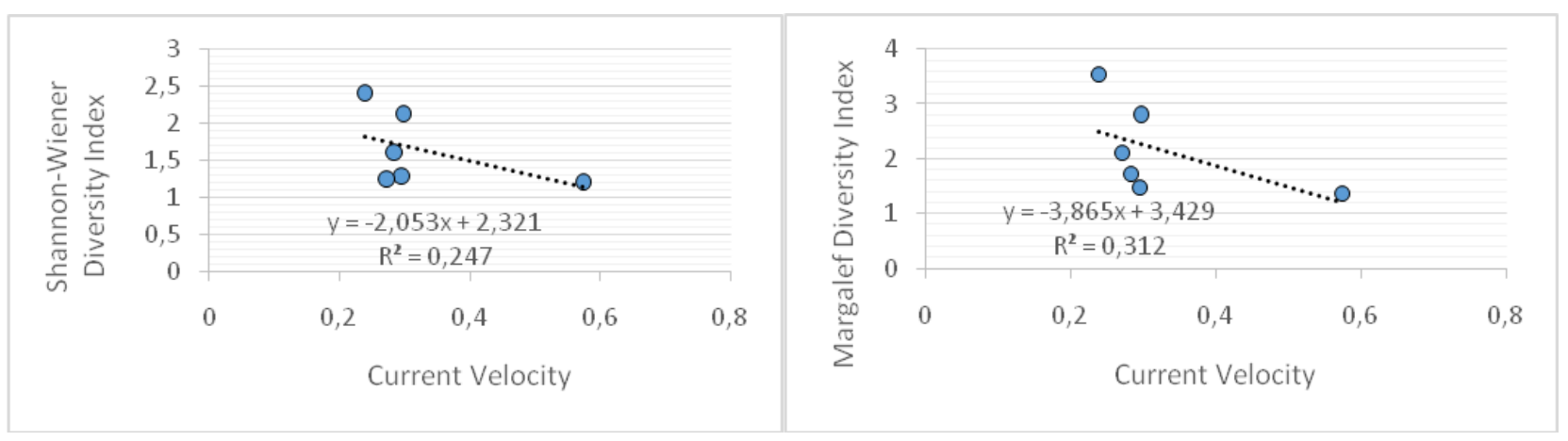

Figure 4. Correlation between current velocity and macroinvertebrate diversity

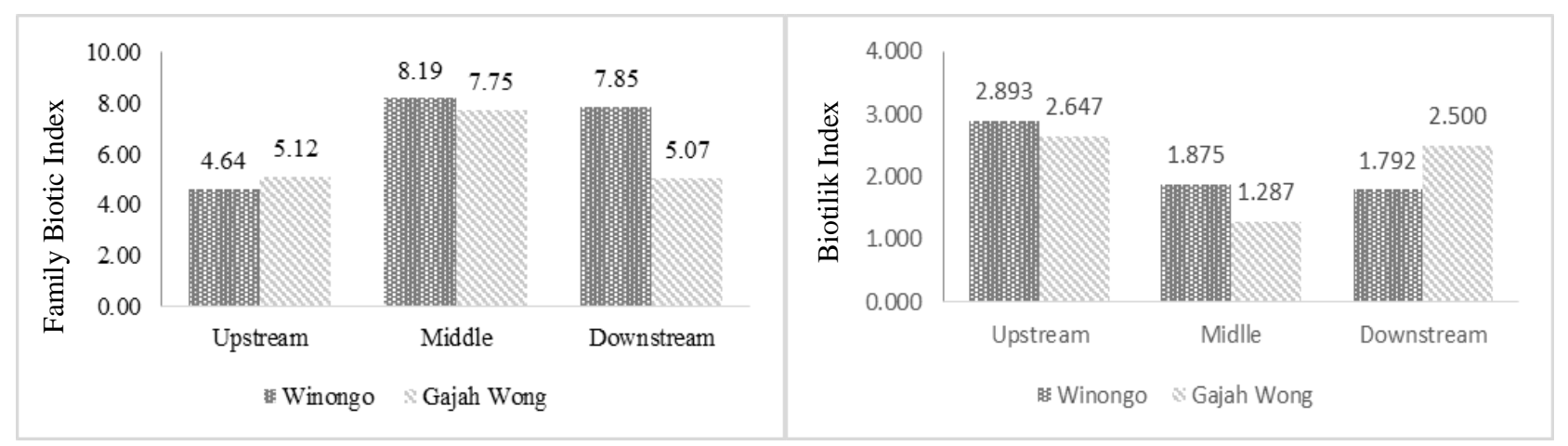

Figure 5. Water quality based on macroinvertebrate diversity at Winongo and Gajah Wong rivers, Yogyakarta, Indonesia 
Table 2. Similarity and dissimilarity of macroinvertebrate at Winongo and Gajah Wong rivers, Yogyakarta, Indonesia

\begin{tabular}{|c|c|c|c|c|c|c|c|}
\hline & & \multirow{2}{*}{\multicolumn{3}{|c|}{ Winongo }} & \multicolumn{3}{|c|}{ Dissimilarity Index } \\
\hline & & & & & & Gajah & \\
\hline & & Upstream & Middle & Downstream & Upstream & Middle & Downstream \\
\hline \multirow{8}{*}{ 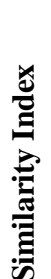 } & Winongo & & & & & & \\
\hline & Upstream & 0 & 94.12 & 71.93 & 69.64 & 89.76 & 81.51 \\
\hline & Middle & 5.88 & 0 & 54.05 & 78.9 & 47.04 & 90.52 \\
\hline & Downstream & 28.07 & 45.95 & 0 & 73.08 & 64.62 & 92.79 \\
\hline & Gajah Wong & & & & & & \\
\hline & Upstream & 30.36 & 21.1 & 26.92 & 0 & 86.81 & 94.5 \\
\hline & Middle & 10.24 & 52.96 & 35.38 & 13.19 & 0 & 87.46 \\
\hline & Downstream & 18.49 & 9.48 & 7.21 & 5.5 & 12.54 & 0 \\
\hline
\end{tabular}

\section{Discussion}

Based on Shannon-Wiener and Margalef diversity indexes, Winongo upstream had the highest score. Winongo upstream consisted of 18 families of macroinvertebrates. Nine of those families, which belong to Ephemeroptera, Plecoptera, and Trichoptera (EPT) orders, were intolerant and tolerant to a slight amount of pollutants. The intolerant members were Heptageniidae, Leptophlebiidae, Perlidae, Chloroperlidae, Philopotamidae, and Brachycentridae, while the semi tolerant ones were Baetidae, Leptoceridae, and Hydropsychidae (Rahayu et al. 2009; Ecoton 2013; Blakely et al. 2014). The other families were Euphaeidae, Vellidae, Palaemonidae, Corixidae, Pleuroceridae, Thiaridae, Simulidae, Parathelpusidae, and Chironomidae. The highest score of evenness index was 0.834 , and the lowest of dominance index was 0.116 . It suggests that there were no dominating families.

The river was shallow and clear, with the substrate composed of sand and rocks. Riverbank was dominated by thorny palm and bamboo plantations. Based on the Family Biotic Index score, Winongo upstream had good water quality with a probability of some organic pollution. Based on the BIOTILIK index, its water quality was slightly polluted. There is not any record of pollutant sources at Winongo upstream yet. The pollutant could be from a thorny palm plantation based on the observation.

Gajah Wong upstream had the second-highest score of Shannon-Wiener diversity, i.e., 2.131. It suggests that the macroinvertebrate diversity of Gajah Wong and Winongo upstreams was the same. They both had moderate ecological conditions (Puente and Diaz 2008). That score also suggests fair diversity and productivity status, fairly balanced ecosystem conditions, and fair ecological pressures (Fitriana 2005).

Macroinvertebrate diversity consisted of 14 families, 5 families belonging to EPT orders, and 8 Non-EPT families. The EPT members were Baetidae, Caenidae, Goeridae, Polymitarcyidae, and Polycentropodidae. Individuals belonging to Polymitarcyidae were the most commonly found. The evenness of the families was high, although the dominance score was low. A shallow and clear water body with a substrate composed of sand and rocks was suitable as a habitat for Polymitarcyidae. Polymitarcyidae burrows in rivers under rocks (Bouchard 2004) or sand. At this station, Gomphidae, Vellidae, Mesoveliidae, Tipulidae, Palaemonidae, and Nepidae families were not significantly tolerant to pollutants. Tolerant families were Chironomidae, Parathelpusidae, and Pleuroceridae (Rahayu et al. 2009; Ecoton 2013; Blakely et al. 2014).

Based on the FBI score, Gajah Wong upstream had fair water quality, which suggests fairly substantial pollution likely, while based on BIOTILIK score, it was slightly polluted. Pollutant sources have not been officially recorded by the environmental institution of the Yogyakarta Special Region. Physically, it was contaminated by the household wastes such as plastic bags. The water body was shallow and clear. Riverbank was in the form of mahogany and thorny palm plantation. There was much water drop from the stone gaps. Rock oxidation level in this area was adequately high.

The diversity status of macroinvertebrates at Winongo and Gajah Wong middle zone was poor ecologically (Puente and Diaz, 2008). Found 8 families at both locations. Families found dominantly were Chironomidae and Glossiphoniidae. Both families were tolerant of pollutants. Chironomidae was the most dominating family at both locations (Rahayu et al., 2009; Blakely et al., 2014).

The water quality of both middle zones was severely polluted. Based on the data provided by the environmental institution of Yogyakarta Special Region year 2015, the pollutants that get into the water bodies at the middle zones result from several sources, such as hospitals, local governmental clinics, maternity hospitals, environmental and health laboratories, metal industries, leather industries, food industries, automotive industries, batik fabric industries, print shops, gas stations, laundries, hotels, malls, and restaurants.

The high pollution level caused the presence of organic nutrients abundantly for Chironomidae (Armitage et al. 1995). Besides, competitors and predators were in small numbers in polluted water bodies.

Winongo and Gajah Wong's middle zones produced a foul odor. Winongo's middle zone was composed of rocks, while Gajah Wong's middle zone was sand and clay. Sand and clay were suitable for habitats of dragonfly nymphs; therefore, they were found in a pretty great number.

At Winongo downstream, found 9 families with 1 family belonging to EPT, i.e., Hydropsychidae, and 8 other families were non-EPT, i.e., Pleuroceridae, Chironomidae, Hirudinidae, Physidae, Glossiphoniidae, Tubificidae, Corixidae, and Atyidae. Individuals belonging to 
Chironomidae were found most abundant. While Gajah Wong downstream had higher diversity, i.e., 11 families with 1 family of EPT, i.e., Hydropsychidae, and 10 family non-EPT, i.e., Thiaridae, Pleuroceridae, Corbiculidae, Viviparidae, Chironomidae, Coenagrionidae, Glossiphoniidae, Corixidae, Hirudinidae, and Parathelpusidae. Hydropsychidae and Thiaridae were found most abundant. Based on the Evenness Index, families found at Winongo downstream were distributed more evenly than Gajah Wong downstream. Based on Dominance Index, Winongo downstream had a lower score than Gajah Wong downstream. It suggests that family evenness at Winongo downstream was higher, and there was no dominating family. While at Gajah Wong downstream, it suggests low family evenness, and there were two dominating families, i.e., Hydropsychidae and Thiaridae.

High diversity is correlated to ecosystem health (Barbour et al. 1999). EPT is a macroinvertebrate group whose presence is limited by pollution and the embeddedness of rocks, which cause the macroinvertebrate habitat to become narrower (Spellman and Drinan 2001). The substrate at both river upstreams was dominated by sand and rocks, but the only EPT member found was Hydropsychidae. At Gajah Wong downstream, Hydropsychidae individuals were found abundantly but less at Winongo downstream. It suggests that the water body condition at Winongo downstream was relatively polluted. FBI score of Winongo downstream was high, i.e., 7.85, which means very poor water quality, while FBI score of Gajah Wong downstream was 5.07, which suggests fair water quality. Based on BIOTILIK Index, the score of Winongo downstream was 1.792, which means poorly healthy water quality, while the score of Gajah Wong downstream was 2.5 , which suggests healthy water quality.

Pollutant sources in downstream areas, based on the data by Badan Lingkungan Hidup or environmental institution of Yogyakarta Special Region year 2015, consisted of hospitals, environmental and health laboratories, metal industries, leather industries, sugar industries, noodle industries, textile industries, alcohol industries, cow husbandries, slaughterhouses, fish canning industries, tofu industries, tempeh industries, batik fabric industries, automotive industries, print shops, gas stations, car wash industries, pharmacies, hotels, and restaurants.

\section{ACKNOWLEDGEMENTS}

We thank Ariyanto Nugroho and Potma Biogama as our most important financial supporters for their help and encouragement. We also thank the Entomology Study Club, Faculty of Biology, Universitas Gajah Mada Yogyakarta, Indonesia, for their support on field and laboratory assessments.

\section{REFERENCES}

Anzani YM. 2012. Makrozoobenthos sebagai Bioindikator Kualitas Perairan di Sungai Ciambulawung, Lebak, Banten. [Skripsi]. Institut Pertanian Bogor, Bogor. [Indonesian]

Armitage P, Cranston PS, Pinder LCV. 1995. The Chironomidae. The Biology and Ecology on Non-Biting Midges. Chapman and Hall, London, UK. DOI: 10.1007/978-94-011-0715-0.

Barbour MT, Gerritsen J, Snyder BD, Stribling JB. 1999. Rapid Bioassessment Protocols for Use in Streams and Wadeable Rivers: Periphyton, Benthic Macroinvertebrates, and Fish, 2nd ed. US Environmental Protection Agency, Washington DC, USA.

Blakely TJ, Eikass HS, Harding JS. 2014. The Singapore: a macroinvertebrate biotic index for assessing the health of Singapore's streams and canals. Raffles Bull Zool 62: 540-548.

BLH Pemerintah Daerah Istimewa Yogyakarta. 2015. Data kualitas air sungai DIY tahun 2015. Daerah Istimewa Yogyakarta Environmental Agency, Yogyakarta. [Indonesian]

BLH Pemerintah Daerah Istimewa Yogyakarta. 2015. Data sumber pencemar tahun 2015. Daerah Istimewa Yogyakarta Environmental Agency, Yogyakarta. [Indonesian]

Bouchard Jr RW. 2004. Guide to Aquatic Macroinvertebrates of the Upper Midwest Water Resources Center. University of Minnesota, St Paul, Minnesota.

Dewi SC. 2013. Keragaman Gastropoda sebagai Bioindikator Kualitas Perairan di Hulu Sub DAS Gajah Wong. [Skripsi]. Universitas Islam Negeri Sunan Kalijaga, Yogyakarta. [Indonesian]

Dudgeon D, Arthington AH, Gessner MO, Kawabata Z, Knowler DJ, Lévêque C, Naiman RJ, Prieur-Richard A, Soto D, Stiassny ML, Sullivan CA. 2006. Freshwater biodiversity: importance, threats, status, and conservation challenges. Biol Rev 81 (2): 163-182. DOI: 10.1017/S1464793105006950.

Ecoton. 2013. Panduan Biotilik Pemantauan Kesehatan Sungai. ECOTON, Gresik. [Indonesian]

Fitriana YR. 2005. Keanekaragaman dan kemelimpahan makrozobentos di hutan magrove hasil rehabilitasi Taman Hutan Raya Ngurah Rai Bali. Biodiversitas 7 (1): 67-72. DOI: 10.13057/biodiv/d070117.

Gamito S. 2009. Caution is needed when applying Margalef Diversity $\begin{array}{llll}\text { Index. Ecol Indic } 10 & \text { (2): 550-551. DOI: }\end{array}$ 10.1016/j.ecolind.2009.07.006.

Giorgio A, Bonis SD, Guida M. 2016. Macroinvertebrate and diatom communities as indicator for the biological assessment of river Picentino (compania, Italy). Ecol Indic 64: 85-91. DOI: 10.1016/j.ecolind.2015.12.001.

Heip C. 1974. A New Index Measuring Evenness. J Mar Biol Assoc UK. 54 (3): 555-557. DOI: 10.1017/S0025315400022736.

Heip CHR, Herman PMJ, Soetaert K. 1998. Indices of diversity and evenness. Oceania 24 (4): 61-87

Jost L. 2010. The relation between evenness and diversity. Diversity 2 (2): 207-232. DOI: 10.3390/d2020207.

Komarawidjaja W, Titiresmi. 2006. Teknik biomonitoring sebagai alternatif "tool" pemantauan kualitas lingkungan perariran. Jurnal Teknologi Lingkungan 144-147. [Indonesian]

Permana DI. 2013. Studi Perubahan Kualitas Air Sungai Winongo Tahun 2003 dan 2012. [Skripsi]. Universitas Gadjah Mada, Yogyakarta. [Indonesian]

Puente A, Diaz RJ. 2008. Is it possible to assess the ecological status of highly stressed natural estuarine environments using macroinvertebrates indices? Mar Pollut Bull 56 (11): 1880-1889. DOI: 10.1016/j.marpolbul.2008.07.016.

Rahayu S, Widodo RH, van Noordwijk M, Suryadi I, Verbist B. 2009. Water Monitoring of Watersheds. World Agroforestry CentreSoutheast Asia Regional Office, Bogor, Indonesia. [Indonesian]

Spellman FR, Drinan JE. 2001. Stream Ecology and Self-Purification. Technomic Publishing Company, Inc. Pennsylvania. DOI: 10.1201/9781420031676.

Stein H, Springer M, Kohlmann B. 2008. Comparison of two sampling methods for biomonitoring using aquatic macroinvertebrates in the Dos Novillos River, Costa Rica. Ecol Eng 34 (4): 267-275. DOI: 10.1016/j.ecoleng.2007.06.010.

Wolda H. 1981. Similarity indices, sample size, and diversity. Oecologia (Berl) 50 (3): 296-302. DOI: 10.1007/BF00344966. 